\title{
Isolation and Identification of Zinc Dissolving Bacteria and Their Potential on Growth of Zea mays
}

\author{
A.A. Omara, Azza A. Ghazi and I.A. El-Akhdar \\ Soil, water and Environment Research Institute, Agricultural \\ Research Center, Cairo, Egypt.
}

\begin{abstract}
7 WENTY-FIVE bacterial isolates were isolated from mature compost and evaluated for their solubilization potential of insoluble zinc oxide and zinc carbonate. An efficient zinc-solubilizing bacterial isolate (Zn14) were chosen. Thereafter, some morphological and biochemical characteristics as well as 16S rRNA sequence indicated that the isolate belonged to Enterobacter cloacae. The effect of various carbon and nitrogen sources on the efficiency of $\mathrm{Zn}$ solubilization were investigated under shaking and static conditions. The selected bacterial strain could solubilize $\mathrm{Zn}$ compounds under a wide range of nutrient types.
\end{abstract}

A pot experiment was conducted at Sakha Agricultural Research Station, Sakha, Kafrelsheikh, Egypt to study the efficiency of using Enterobacter cloacae as an in vivo $\mathrm{Zn}$ solubilizer either alone or with amended zinc compounds $\left(\mathrm{ZnO}\right.$ and $\left.\mathrm{ZnCO}_{3}\right)$ to the soil and its effect on growth parameters of Zea mays under sterile and non-sterile soil at the age of 30 and 60 days.

There was a highly significant response for increased $\mathrm{Zn}$ uptake in all treatments compared to the control. The treatment with $\mathrm{ZnO}$ and $E$. cloacae was the more effective in terms of total chlorophyll plant dry weight compared to the control.

To solve zinc nutrition problem using a biofertilizer, it is obvious that $E$. cloacae is capable of solubilizing insoluble zinc compounds by inoculation to increase crop growth and improve soil fertility.

Keywords: $\mathrm{ZnO}, \mathrm{ZnCO}_{3}$, Enterobacter cloacae, Zea mays

Zinc is one of the eight essential trace elements or micronutrients needed for the normal healthy growth and reproduction of crop plants, and it is vital to the crop nutrition as required in various enzymatic reactions, oxidation reduction reactions and metabolic processes, which requires in relatively small concentrations in plant tissues (5-100 $\mathrm{mg} \mathrm{kg}^{-1}$ ) (Parker et al., 1992). Furthermore, $\mathrm{Zn}$ is also essential for many enzymes that are needed for nitrogen metabolism, protein synthesis and energy transfer. Insufficiency retards growth and yield of plants, but it also affects humans. More than 3 billion people worldwide suffer from $\mathrm{Zn}$ deficiencies (Hafeez et al., 2013). 
Normal soils inherit their micro elements which contain Zn, primarily from rocks through pedochemical and geochemical weathering processes. In addition, mineralogical composition of the parent material and the total amount of $\mathrm{Zn}$ in the soil during the process of soil formation are also dependent on the type, intensity of weathering, climate and numerous other factors (Saeed \& Fox, 1977). Meanwhile, increase in $\mathrm{pH}$ and contents of $\mathrm{CaCO}_{3}$, clay, phosphate and organic matter can fix $\mathrm{Zn}$ in the soil and cause the reduction of available $\mathrm{Zn}$ (Imtiaz, 1999). According to the Food and Agriculture Organization (Sillanpaa, 1990) about $30 \%$ of the cultivable soils of the world includes low levels of available $\mathrm{Zn}$ to the plant due to the low solubility of $\mathrm{Zn}$ in soils rather than a low total amount of $\mathrm{Zn}$.

Zinc plays a role inside the cell, which affects the proper functioning of enzymes that perform a pivotal role in more than 300 enzymes (Vallee, 1991) and it found in all enzyme classes (transferases, oxidoreductases, lyases, hydrolases, ligases and isomerases). Some of these enzymes are involved in $\mathrm{CO}_{2}$ regulation digestion of proteins, as well as found in DNA-binding proteins.

In the rhizosphere, it is important to study the interactions between plants, soil and microorganisms especially solubilization of insoluble $\mathrm{Zn}$ compounds and the benefits for crops. Many bacteria can solubilize $\mathrm{Zn}$ compounds, these include: Microbacterium saperdae, Pseudomonas monteilli (Whiting et al., 2001), Pseudomonas fluorescens (Di Simine et al., 1998) and Pseudomonas aeruginosa (Fasim et al., 2002). The mechanisms of solubilization of $\mathrm{Zn}$ compounds are dependent on production of organic acids, especially 2-ketogluconic acid and $\mathrm{H}^{+}$, as well as other metabolites, siderophores, and $\mathrm{CO}_{2}$ from respiration. These processes are variable due to the organisms and the growth conditions (Nautiyal, et al., 2000).

Maize (Zea mays L.) is one of the cereal crops produced more than other cereal grain worldwide (FAO, 2011). It is an important cereal crop in nutrition for humans, poultry, and livestock (Nuss \& Tanumihardjo, 2010). Thus, it's important to increase $\mathrm{Zn}$ concentration in maize grain for people whose diet relies directly or indirectly on maize-derived food.

In last decades, Zinc deficiency in the soil-crop system has become more prevalent so that maize is consider the most susceptible cereal crop to $\mathrm{Zn}$ deficiency due to high yielding maize varieties which are selectively grown with chemical fertilizers to improve the cropping and quality (Fageria et al., 2002).

Zinc applications are reported to increase in maize plant around world (Hossain et al., 2008 and Potarzycki \& Grzebisz, 2009). Biofertilization is an effective strategy, which has been well documented to increase $\mathrm{Zn}$ levels in wheat and rice (Cakmak, 2008 and Shivay et al., 2008). Recent studies indicated that it's possible to increase $\mathrm{Zn}$ levels in maize by increasing soil $\mathrm{Zn}$ fertilizer or using biofertilizers to transfer insoluble Zn compounds form to soluble forms (Harris et al., 2007).

Egypt. J. Microbiol. 51 (2016) 
Whiting et al. (2001) discuss the efficiency of $\mathrm{Zn}$ solubilizing bacterial strains isolated from the rhizosphere of a $\mathrm{Zn}$ hyper-accumulating plant Thlaspi caerulescens that has $\mathrm{Zn}$ concentration greater than $10,000 \mathrm{mg} \mathrm{g}^{-1}$ of plant tissue. These strains were inoculated into the rhizosphere of the germinating seeds of Thlaspi plants, the bacteria increased the water soluble $\mathrm{Zn}$ portion in the soil system and increasing $\mathrm{Zn}$ concentrations in roots and shoots $22-67 \%$ higher than the control. The maximum increases in $\mathrm{Zn}$ uptake and all plant growth parameters of Vigna radiata was seen when seedlings were inoculated with $\mathrm{Zn}$ solubilizing bacteria (Iqbal et al., 2010).

In this study, we report the isolation, characterization, and identification of a $\mathrm{Zn}$ solubilizing bacterial isolate, and its ability to enhance the growth of Zea mays plants.

\section{Materials and Methods}

Microorganism and growth conditions

Twenty five bacterial isolates from mature compost were screened for its ability to solubilize zinc compounds based on clear zone formation on the modified Bunt and Rovira medium described by Abdel Hafez (1966) which containing gl ${ }^{-1}\left(0.4 \mathrm{KH}_{2} \mathrm{PO}_{4}, 0.5\left(\mathrm{NH}_{4}\right)_{2} \mathrm{SO}_{4}, 0.5 \mathrm{MgSO}_{4} \cdot 7 \mathrm{H}_{2} \mathrm{O}, 0.1 \mathrm{MgCl}_{2}, 0.1\right.$ $\mathrm{FeCl}_{3}, 0.1 \mathrm{CaCl}_{2}, 1.0$ peptone, 1.0 yeast extract, 5.0 glucose, $250.0 \mathrm{ml}$ soil

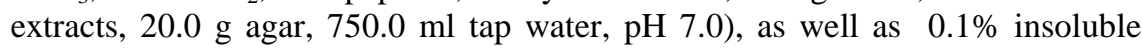
$\mathrm{ZnO}$ and $\mathrm{ZnCO}_{3}$ as described by Saravanan et al. (2003). The test organisms were inoculated by stab onto agar plats and incubated at $30^{\circ} \mathrm{C}$ for $48 \mathrm{~h}$. The diameters of clear zone around the colonies were measured and the best one was chosen. Pure isolate were maintained on nutrient agar slants at $4{ }^{\circ} \mathrm{C}$ in a refrigerator for further use.

\section{Characterization of the selected isolate}

One selected isolate was characterized based on morphological, biochemical, and culturing characteristics according to Bergy \& Holt (1984) and Somasegaran \& Hoben (1985).

Molecular identification on the basis of $16 S$ rRNA

The most effective isolates for zinc solubilizing were chosen to identify by polymerase chain reaction (PCR) at Sigma Scientific Services Co., Giza, Egypt. Genomic DNA of the test bacterial isolates grown on nutrient broth was extracted with GeneJet Bacterial Genomic DNA Extraction Kit (Fermentas). The $16 \mathrm{~S}$ rRNA gene of the isolate was amplified by using universal primers Forward and Reverse (F, 5-AGA GTT TGA TCC TGG CTC AG-3 and R, 5- GGT TAC CTT GTT ACG ACT T-3) used to obtain a PCR product of $1.5 \mathrm{~kb}$. The sample was placed in a hybridthermal reactor thermocycler (Maxima Hot Start PCR Master Mix (Fermentas), initially denatured (enzyme activation) for $10 \mathrm{~min}$ at $95^{\circ} \mathrm{C}$ for one cycle and denaturated for $30 \mathrm{~s}$ at $95^{\circ} \mathrm{C}$, annealing for $1 \mathrm{~min}$ at $65^{\circ} \mathrm{C}$ then extention for $1 \mathrm{~min}$ at $72^{\circ} \mathrm{C}$. This was followed by a final elongation step for 
$10 \mathrm{~min}$ at $72^{\circ} \mathrm{C}$. The PCR products were analyzed on $1 \%(\mathrm{w} / \mathrm{v})$ agarose gels and sent to GATC (Germany) for sequencing using ABI 3730xl DNA sequencer.

Sequence data were imported into the BioEdit version 5.0.9 sequence editor; basecalling was examined, and a contiguous sequence was obtained. The full sequence was aligned using the RDP Sequence Aligner program. Sequences used in the phylogenetic analysis were obtained from the RDP and GenBank databases. A dendrogram was constructed using the neighbour-joining method. Also, confidence in tree topology was determined.

\section{Effect of various nutrient parameters on efficiency of Zn solubilization \\ Carbon sources}

In this experiment modified Bunt and Rovira broth medium was used where glucose present originally in these medium was substituted with different carbon sources included glucose, sucrose, mannitol, fructose, starch, galactose, sodium citrate, sodium acetate, carboxy methyl cellulose and dextrose. Carbon sources stock solutions were sterilized by filtration and added to the broth medium.

\section{Nitrogen sources}

Different nitrogen sources included ammonium sulphate, ammonium chloride, urea, sodium nitrate, peptone, yeast extract, ammonium molybdate or ammonium oxalate were used.

With different carbon and nitrogen sources, the flasks contain the modified Bunt and Rovira medium and/or $0.1 \%$ insoluble $\mathrm{ZnO}$ and $\mathrm{ZnCO}_{3} .0 .5 \mathrm{ml}$ suspension of the test culture strain with a cell load of $1 \times 10^{8}$ cells ml $^{-1}$ were inoculated and incubated at $30^{\circ} \mathrm{C}$ and $150 \mathrm{rpm}$. Experiments were done under shaking and static conditions in triplicate. After $48 \mathrm{~h}$, the samples were withdrawn and centrifuged at $15^{\circ} \mathrm{C}$ and $6000 \mathrm{rpm}$ to remove the cells and debris. Twenty $\mathrm{ml}$ of this solution was fed to Atomic Absorption Spectrophotometry (AAS) PERKIN ELIMER 3300 to determine the available Zn content.

\section{Determination of $p H$}

The $\mathrm{pH}$ of the $\mathrm{Zn}$ solubilizing bacterial culture filtrates samples were determined at 48h after inoculation. The $\mathrm{pH}$ was determined using $\mathrm{pH}$ meter HANNA HI 98127 and compared with the uninoculated control.

\section{Pot experiment}

A pot experiment was carried out in a greenhouse at Sakha Agricultural Research Station, Sakha, Kafr el-sheikh, Egypt. The greenhouse used for this study was basically an open net house. The mean temperature during the experimental period (June to July 2015) ranged from $30^{\circ} \mathrm{C}$ to $40^{\circ} \mathrm{C}$ with a $10-12-\mathrm{h}$ daylight and $60-65 \%$ relative humidity. The experimental plan was based on six treatments. These were T1, control (no Zn source, no Enterobacter cloacae); T2, inoculation with Enterobacter cloacae (Zn solubilizer); T3, $\mathrm{ZnO}$ alone; $\mathrm{T} 4, \mathrm{ZnCO}_{3}$ alone; $\mathrm{T} 5, \mathrm{ZnO}+$ Enterobacter cloacae ( $\mathrm{Zn}$ solubilizer); T6, 
$\mathrm{ZnCO}_{3}+$ Enterobacter cloacae ( $\mathrm{Zn}$ solubilizer). The experiment was conducted in a split plot design under sterile and non-sterile soil conditions with four replicates.

Soil used

The pot experiment was conducted in silty clay soil in texture having the following characteristics: $\mathrm{pH}, 8.11$; EC, $0.186 \mathrm{dSm}^{-1}$; organic matter (\%), 1.12; particle size distribution sand, silt and clay (\%), 33.65, 24.17 and 42.18, respectively; soluble cations $\mathrm{Ca}^{+2}, \mathrm{Mg}^{+2}, \mathrm{Na}^{+}$and $\mathrm{K}^{+}$(meq L $\mathrm{L}^{-1}$ ), $0.86,0.49,0.50$ and 0.12 , respectively; soluble anions $\mathrm{CO}_{3}^{-}, \mathrm{HCO}_{3}^{-}, \mathrm{Cl}^{-}$and $\mathrm{SO}_{4}^{-}$(meq L $\left.\mathrm{L}^{-1}\right), 0.0,1.0,0.66$ and 0.31 , respectively; available $\mathrm{N}$ $\left(\mathrm{mg} \mathrm{kg}^{-1}\right), 6.44$; available $\mathrm{P}\left(\mathrm{mg} \mathrm{kg}^{-1}\right), 5.80$; available $\mathrm{K}\left(\mathrm{mg} \mathrm{kg}^{-1}\right), 351.1$; available $\mathrm{Zn}$ $\left(\mathrm{mg} \mathrm{kg}^{-1}\right), 17.39$. Also, total count of bacteria, $150 \times 10^{6} \mathrm{CFU} \mathrm{g}^{-1}$; total count of fungi, 75 $\mathrm{x} 10^{4} \mathrm{CFU} \mathrm{g}^{-1}$; and total count of actinbacteria, $45 \times 10^{5} \mathrm{CFU} \mathrm{g}^{-1}$ (Allen, 1959). These soil was put in pots of $30 \mathrm{~cm}$ diameter and $35 \mathrm{~cm}$ depth at the rate of $6 \mathrm{~kg}$ soil pot ${ }^{-1}$. The soil moisture maintained at $60 \%$ of water holding capacity. The mineral fertilizers were added as recommended by Egyptian Ministry of Agriculture for mineral fertilizers which comprised Urea $(46.5 \% \mathrm{~N})$ with the rate of $1.2 \mathrm{~g} \mathrm{pot}^{-1}$, calcium super-phosphate $(15 \%$ $\mathrm{P}_{2} \mathrm{O}_{5}$ ) with the rate of $1.2 \mathrm{~g} \mathrm{pot}^{-1}$, potassium sulphate $\left(48 \% \mathrm{~K}_{2} \mathrm{O}\right)$ with the rate of $0.3 \mathrm{~g}$ pot ${ }^{1}$ and $\mathrm{Zn}$ source fertile $\left(\mathrm{ZnO}\right.$ or $\left.\mathrm{ZnCO}_{3}\right)$ with the rate of $0.048 \mathrm{~g} \mathrm{pot}^{-1}$.

\section{Preparation of Enterobacter cloacae inoculum}

A loop full of nutrient agar slant Enterobacter cloacae KX034162 cells was cultivated in $250 \mathrm{ml}$ nutrient broth medium in 500 Erlenmeyer flask at $30^{\circ} \mathrm{C}$ on a rotary shaker for $24 \mathrm{~h}$ at $150 \mathrm{rpm}$. All plants were inoculated with bacterial suspension $3 \mathrm{ml}$ plant $^{-1}$ as shown from plate counting technique, this procedure yielded $10^{7}-10^{8} \mathrm{CFU} \mathrm{ml} l^{-1}$.

\section{Grains used}

Grain of maize (Zea mays L. cv. Hybrid 10) was surface sterilized in a 3.5\% (w/v) solution of calcium hypochlorite for $10 \mathrm{~min}$ then immersed in distilled water several times then one grain was sown in each pot. The grains were kindly supplied by Field Crops Research Institute, Department of Cereal Crops, Sakha Agricultural Research Station, ARC.

\section{Estimation of available zinc content in soil}

Available zinc content of the soil was estimated using the diethylene triamine penta acetic acid extract following the method of Lindsay and Norvell (1978).

\section{Chemical component assay of plant materials}

The shoots were harvested at 30 and 60 days after sowing, rinsed twice in distilled water, dried at $80^{\circ} \mathrm{C}$ for three days, and dry weight plant ${ }^{-1}$ determined as well as their $\mathrm{Zn}$ content were determined by atomic absorption technique (PERKIN ELIMER 3300) according to Cottenie et al. (1982). Equipments were calibrated and uncertainties were calculated. Internal and external quality assurance systems were applied in the laboratory according to ISO/IEC 17025 requirements for laboratory accreditation. In all measurements, blanks, triplicate measurements of metals in extracts, and analysis of certified reference materials for each metal (Merck) were routinely included for quality control. 
Total chlorophyll determination

Total chlorophyll was estimated by Minolta chlorophyll metter SPAD-502 in the green house after 30 and 60 days of sowing.

\section{Statistical analysis}

Data obtained were subjected to the analysis of variance and treatment means were compared using the L.S.D methods according to Steel \& Torrie (1981).

\section{Results and discussion}

Isolation and screening of Zinc solubilizing bacteria in solid medium

One of 25 isolates was screened according to hydrolysis capacity (HC) using the diameter of clear zone and diameter of colony on the modified Bunt and Rovira solid medium containing insoluble $\mathrm{ZnO}$ and $\mathrm{ZnCO}_{3}$ to select the most potent $\mathrm{Zn}$ solubilizing (Fig. 1 and Tables 1, 2).

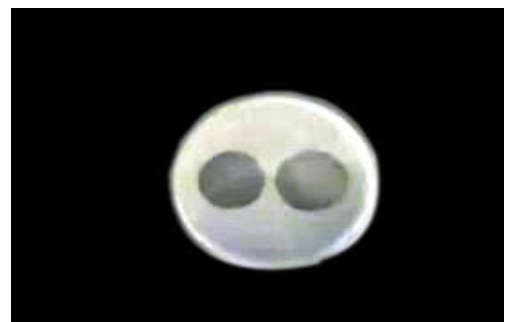

A

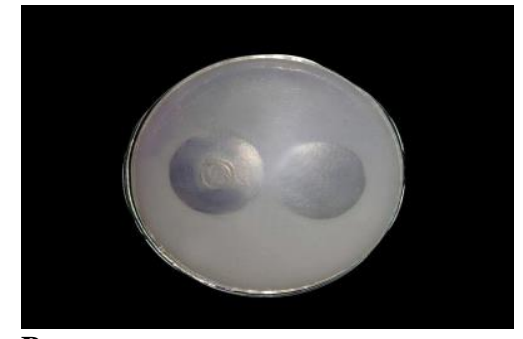

B

Fig. 1. Clear zone of $\mathrm{Zn14}$ on the modified Bunt and Rovira media agar plates. A) $\mathrm{ZnO}$ B) $\mathrm{ZnCO}_{3}$ each at $0.1 \%$.

TABLE 1. Solubilization capacity of zinc oxide by isolates under study.

\begin{tabular}{|c|c|c|c|c|c|c|c|}
\hline $\begin{array}{c}\text { Code of } \\
\text { bacterial } \\
\text { isolate }\end{array}$ & $\begin{array}{l}\text { Colony } \\
\text { diameter } \\
\text { (cm) }\end{array}$ & $\begin{array}{l}\text { Clear zone } \\
\text { Diameter } \\
\quad(\mathrm{cm})\end{array}$ & HC value & $\begin{array}{c}\text { Code of } \\
\text { bacterial } \\
\text { isolate }\end{array}$ & $\begin{array}{l}\text { Colony } \\
\text { diameter } \\
\text { (cm) }\end{array}$ & $\begin{array}{c}\text { Clear zone } \\
\text { diameter } \\
(\mathrm{cm})\end{array}$ & $\begin{array}{c}\mathrm{HC} \\
\text { value }\end{array}$ \\
\hline $\mathrm{Zn} 1$ & $0.43 \pm 0.01$ & $1.3 \pm 0.11$ & 3.02 & $\mathrm{Zn} 14$ & $0.48 \pm 0.01$ & $2.6 \pm 0.06$ & 5.42 \\
\hline $\mathrm{Zn} 2$ & $0.13 \pm 0.00$ & 0 & 0 & $\mathrm{Zn} 15$ & $0.61 \pm 0.01$ & $1.36 \pm 0.09$ & 2.23 \\
\hline $\mathrm{Zn} 3$ & $0.39 \pm 0.001$ & $1.54 \pm 0.03$ & 3.95 & $\mathrm{Zn} 16$ & $0.47 \pm 0.05$ & $2.36 \pm 0.06$ & 5.02 \\
\hline $\mathrm{Zn} 4$ & $0.22 \pm 0.002$ & 0 & 0 & $\mathrm{Zn17}$ & $0.53 \pm 0.03$ & $1.15 \pm 0.07$ & 2.17 \\
\hline $\mathrm{Zn5}$ & 0 & 0 & 0 & Zn18 & $0.36 \pm 0.01$ & $1.41 \pm 0.02$ & 3.92 \\
\hline Zn6 & $0.44 \pm 0.005$ & $2.1 \pm 0.14$ & 4.77 & Zn19 & $0.60 \pm 0.02$ & $1.99 \pm 0.15$ & 3.32 \\
\hline $\mathrm{Zn} 7$ & $0.31 \pm 0.00$ & $1.25 \pm 0.17$ & 4.03 & $\mathrm{Zn} 20$ & 0 & 0 & 0 \\
\hline Zn8 & $0.16 \pm 0.006$ & 0 & 0 & $\mathrm{Zn} 21$ & $0.36 \pm 0.00$ & $1.46 \pm 0.05$ & 4.05 \\
\hline $\mathrm{Zn} 9$ & $0.52 \pm 0.01$ & $0.66 \pm 0.03$ & 1.27 & $\mathrm{Zn} 22$ & $0.65 \pm 0.02$ & $1.81 \pm 0.02$ & 2.78 \\
\hline $\mathrm{Zn} 10$ & $0.15 \pm 0.00$ & 0 & 0 & $\mathrm{Zn} 23$ & $0.12 \pm 0.00$ & 0 & 0 \\
\hline $\mathrm{Zn} 11$ & $0.31 \pm 0.006$ & $0.65 \pm 0.03$ & 2.1 & $\mathrm{Zn} 24$ & 0 & 0 & 0 \\
\hline $\mathrm{Zn} 12$ & $0.57 \pm 0.03$ & $1.86 \pm 0.09$ & 3.26 & $\mathrm{Zn} 25$ & $0.53 \pm 0.02$ & $1.11 \pm 0.00$ & 2.09 \\
\hline $\mathrm{Zn13}$ & $0.45 \pm 0.02$ & $1.69 \pm 0.15$ & 3.75 & & & & \\
\hline
\end{tabular}

Egypt. J. Microbiol. 51 (2016) 
TABLE 2. Solubilization capacity of zinc carbonate by isolates under study.

\begin{tabular}{|l|c|c|c|c|c|c|c|}
\hline $\begin{array}{l}\text { Code of } \\
\text { bacterial } \\
\text { isolate }\end{array}$ & $\begin{array}{c}\text { Colony } \\
\text { diameter } \\
(\mathbf{c m})\end{array}$ & $\begin{array}{c}\text { Clear zone } \\
\text { diameter } \\
(\mathbf{c m})\end{array}$ & HC value & $\begin{array}{c}\text { Code of } \\
\text { bacterial } \\
\text { isolate }\end{array}$ & $\begin{array}{c}\text { Colony } \\
\text { diameter } \\
(\mathbf{c m})\end{array}$ & $\begin{array}{c}\text { Clear zone } \\
\text { diameter } \\
(\mathbf{c m})\end{array}$ & $\begin{array}{c}\text { HC } \\
\text { value }\end{array}$ \\
\hline $\mathrm{Zn} 1$ & $0.39 \pm 0.01$ & $1.10 \pm 0.12$ & 2.82 & $\mathrm{Zn} 14$ & $0.50 \pm 0.01$ & $2.39 \pm 0.06$ & 4.78 \\
\hline $\mathrm{Zn} 2$ & $0.11 \pm 0.00$ & 0 & 0 & $\mathrm{Zn} 15$ & $0.67 \pm 0.01$ & $1.40 \pm 0.09$ & 2.08 \\
\hline $\mathrm{Zn} 3$ & $0.39 \pm 0.001$ & $1.30 \pm 0.11$ & 3.33 & $\mathrm{Zn} 16$ & $0.57 \pm 0.08$ & $2.28 \pm 0.04$ & 4.0 \\
\hline $\mathrm{Zn} 4$ & $0.24 \pm 0.002$ & 0 & 0 & $\mathrm{Zn} 17$ & $0.50 \pm 0.03$ & $1.11 \pm 0.06$ & 2.22 \\
\hline $\mathrm{Zn} 5$ & 0 & 0 & 0 & $\mathrm{Zn} 18$ & $0.32 \pm 0.01$ & $1.30 \pm 0.02$ & 4.06 \\
\hline $\mathrm{Zn} 6$ & $0.40 \pm 0.005$ & $1.80 \pm 0.11$ & 4.5 & $\mathrm{Zn} 19$ & $0.68 \pm 0.06$ & $1.85 \pm 0.15$ & 2.72 \\
\hline $\mathrm{Zn} 7$ & $0.30 \pm 0.00$ & $1.11 \pm 0.14$ & 3.7 & $\mathrm{Zn} 20$ & 0 & 0 & 0 \\
\hline $\mathrm{Zn} 8$ & $0.12 \pm 0.005$ & 0 & 0 & $\mathrm{Zn} 21$ & $0.39 \pm 0.00$ & $1.49 \pm 0.06$ & 3.82 \\
\hline $\mathrm{Zn} 9$ & $0.48 \pm 0.01$ & $0.71 \pm 0.03$ & 1.47 & $\mathrm{Zn} 22$ & $0.60 \pm 0.02$ & $1.77 \pm 0.02$ & 2.95 \\
\hline $\mathrm{Zn} 10$ & $0.17 \pm 0.00$ & 0 & 0 & $\mathrm{Zn} 23$ & $0.14 \pm 0.00$ & 0 & 0 \\
\hline $\mathrm{Zn} 11$ & $0.31 \pm 0.006$ & $0.72 \pm 0.03$ & 2.32 & $\mathrm{Zn} 24$ & 0 & 0 & 0 \\
\hline $\mathrm{Zn} 12$ & $0.51 \pm 0.02$ & $1.65 \pm 0.07$ & 3.23 & $\mathrm{Zn} 25$ & $0.61 \pm 0.02$ & $1.14 \pm 0.00$ & 1.86 \\
\hline $\mathrm{Zn} 13$ & $0.41 \pm 0.02$ & $1.79 \pm 0.17$ & 4.36 & & & &
\end{tabular}

Hydrolysis capacity (HC): diameter of clear zone / diameter of colony

\section{Characterization of rhizobacterial isolate $\mathrm{Zn} 14$}

A rhizobacterial isolate designated as $\mathrm{Zn} 14$ was recovered from mature compost. The isolate was characterized by morphological and biochemical reactions and 16S rRNA gene sequencing methods (Table 3). The morphological characterization revealed that the colony morphology of the isolate was circular, with entire margin, smooth, peach colored, gram and endospore negative with a small rod shaped. Under in vitro liquid conditions, the isolate grew on MacConkey broth and was positive toward motility and Indole Acetic Acid production, Voges-Proskauer, citrate utilization, oxidase, catalase and urease. Negative results occurred for starch, gelatin and casein hydrolysis. Phylogenetic analysis based on $16 \mathrm{~S}$ rRNA gene sequence $(1.5 \mathrm{~kb})$ indicated that isolate was found to be closely related to Enterobacter cloacae strain ATCC 13047 (99.1\%). Sequence data were submitted to GenBank and it provided a GenBank accession number KX034162 as shown in Fig. 2.

TABLE 3. Some morphological, biochemical characterizations and 16S rRNA gene sequencing of studied rhizobacterial isolate $\mathrm{Zn} 14$.

\begin{tabular}{|l|c|c|c|}
\hline Characteristics & Response & Characteristics & Response \\
\hline Colony configuration & Circular & Gram reaction & - \\
\hline Colony margin & Entire & Cell shape & Rod \\
\hline Colony surface & Smooth & Endospore & - \\
\hline Colony pigmentation & Peach color & Motility & + \\
\hline Indole production & + & Oxidase & + \\
\hline Methyl red test & - & Catalase & + \\
\hline Voges-Proskauer test & + & Urease & + \\
\hline $\begin{array}{l}\text { Growth on MacConkey } \\
\text { broth }\end{array}$ & + & Starch hydrolysis & - \\
\hline Citrate utilization & + & Gelatin hydrolysis & - \\
\hline $\mathrm{H}_{2}$ S production & - & Casein hydrolysis & - \\
\hline
\end{tabular}

+: Positive; -: Negative 


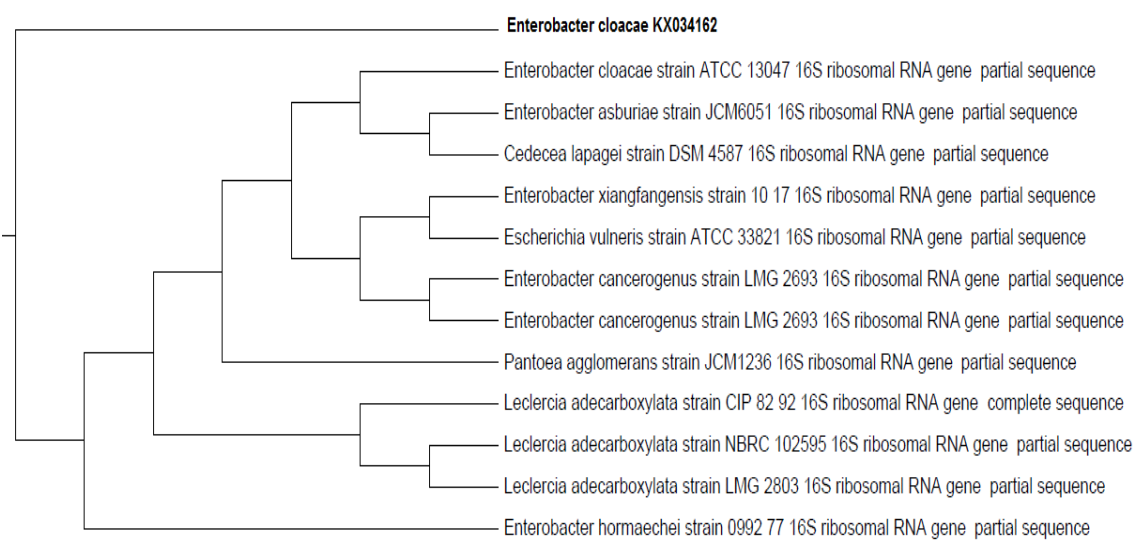

Fig. 2. Neighbor-joining phylogenetic tree reconstructed on the basis of 16S rRNA gene sequence (1.5 kb) showing the phylogenetic Enterobacter cloacae KX034162

Effect of various nutrient parameters on efficiency of zinc solubilization

The observations reported during the growth of liquid cultures of E. cloacae KX034162 under different carbon and nitrogen sources on zinc solubilizing are recorded in Table 4. In general, analysis of the supernatant, performed by atomic absorption technique, showed an increase in the concentration of soluble $\mathrm{Zn}$ with decrease in $\mathrm{pH}$. Also, during the time course of the experiment, the increased $\mathrm{Zn}$ concentration caused by shaking as compared with static conditions.

The best carbon source was glucose followed by succrose and galactose, (530.00, 512.98 and $500.22 \mathrm{mg} \mathrm{L}^{-1} \mathrm{Zn}$ solubilization, respectively) under shaking conditions for $\mathrm{ZnO}$. Results of $\mathrm{ZnCO}_{3}$ followed the same trend.

On the other hand, ammonium chloride was a nitrogen source giving the highest values of $\mathrm{Zn}$ solubilizing $\left(\mathrm{mg} \mathrm{L}^{-1}\right), 830.88$ and 751.98 for $\mathrm{ZnO}$ and 848.00 and 768.43 for $\mathrm{ZnCO}_{3}$ under shaking and static conditions, respectively.

Colonies of the microorganism produced clear halos on solid medium incorporating zinc phosphate or Zn solubilization in liquid culture when glucose was provided as the carbon source (Di Simine et al., 1998).

Morley et al. (1996) and Nautiyal et al. (2000) showed that production of organic acids and $\mathrm{H}^{+}$appear to be the most significant mechanisms for heterotrophic metal solubilization although some contribution may also arise from excretion of other metabolites, siderophores and $\mathrm{CO}_{2}$ from respiration, the significance of all these processes being variable and dependent on the organisms and the growth conditions. The gluconic acid is subsequently taken up by transport systems of the cell and utilized by cellular metabolic pathways; the

Egypt. J. Microbiol. 51 (2016) 
external oxidation of glucose therefore usually produces only transient increases in the concentration of gluconic acid (Drosinos \& Board, 1994).

TABLE 4. Effect of $E$. cloacae $\mathrm{KX034162}$ solubilizing $\mathrm{ZnO}$ and $\mathrm{ZnCO}_{3}$ under different carbon, nitrogen sources and final $\mathrm{pH}$.

\begin{tabular}{|c|c|c|c|c|c|c|}
\hline \multirow{3}{*}{ Carbon source } & \multicolumn{3}{|c|}{$\mathrm{ZnO}$} & \multicolumn{3}{|c|}{$\mathrm{ZnCO}_{3}$} \\
\hline & \multirow{2}{*}{$\begin{array}{c}\text { Final } \\
\text { pH }\end{array}$} & \multicolumn{2}{|c|}{$\begin{array}{l}\text { Zn concentration } \\
\left(m g \mathbf{L}^{-1}\right)\end{array}$} & \multirow{2}{*}{$\begin{array}{c}\text { Final } \\
\text { pH }\end{array}$} & \multicolumn{2}{|c|}{$\begin{array}{c}\text { Zn concentration } \\
\left(\mathrm{mg} \mathrm{L}^{-1}\right)\end{array}$} \\
\hline & & Shaking & Static & & Shaking & Static \\
\hline Glucose & 7.1 & 530.00 & 481.57 & 5.9 & 753.75 & 680.33 \\
\hline Succrose & 7.3 & 512.98 & 466.74 & 7.1 & 513.88 & 436.71 \\
\hline Mannitol & 7.4 & 496.11 & 433.95 & 7.5 & 494.23 & 410.65 \\
\hline Fructose & 7.4 & 492.64 & 427.27 & 7.4 & 505.43 & 422.01 \\
\hline Starch & 7.6 & 460.44 & 394.88 & 7.5 & 478.10 & 424.96 \\
\hline Galactose & 7.3 & 500.22 & 456.32 & 6.5 & 708.45 & 640.50 \\
\hline Sod. citrate & 7.9 & 238.55 & 181.74 & 8.7 & 113.12 & 60.77 \\
\hline Sod. acetate & 7.8 & 246.99 & 182.70 & 8.3 & 138.43 & 82.87 \\
\hline CMC & 7.9 & 229.01 & 166.98 & 8.0 & 145.55 & 89.35 \\
\hline Dextrose & 7.5 & 482.66 & 412.89 & 7.7 & 251.00 & 184.98 \\
\hline \multirow{3}{*}{ Nitrogen source } & \multicolumn{3}{|c|}{$\mathrm{ZnO}$} & \multicolumn{3}{|c|}{$\mathrm{ZnCO}_{3}$} \\
\hline & pH & \multicolumn{2}{|c|}{$\begin{array}{l}\text { Zn concentration } \\
\left(\mathrm{mg} \mathrm{L}^{-1}\right)\end{array}$} & pH & \multicolumn{2}{|c|}{$\begin{array}{l}\text { Zn concentration } \\
\left(\mathrm{mg} \mathrm{L}^{-1}\right)\end{array}$} \\
\hline & & Shaking & Static & & Shaking & Static \\
\hline Amm. sulphate & 4.3 & 822.61 & 750.50 & 4.0 & 853.74 & 779.86 \\
\hline Amm. chloride & 4.1 & 830.88 & 751.98 & 4.0 & 848.00 & 768.43 \\
\hline Urea & 5.1 & 796.32 & 719.04 & 4.8 & 817.00 & 740.23 \\
\hline Sod. nitrate & 5.6 & 784.54 & 698.00 & 5.0 & 801.00 & 739.98 \\
\hline Peptone & 5.0 & 804.29 & 736.98 & 4.8 & 815.35 & 738.93 \\
\hline Yeast extract & 5.9 & 763.75 & 691.33 & 5.5 & 788.98 & 703.21 \\
\hline Amm. molybdate & 5.3 & 792.00 & 711.34 & 5.0 & 807.00 & 743.90 \\
\hline Amm. oxlate & 5.3 & 790.88 & 714.97 & 4.9 & 815.85 & 744.12 \\
\hline
\end{tabular}

Pot experiment

Total chlorophyll content and dry weight ( $g$ plant $\left.{ }^{-1}\right)$

Significant variations among the treatments were observed in total chlorophyll content and dry weight $\left(\mathrm{g}\right.$ plant $\left.^{-1}\right)$ of Zea mays plants at two stages of crop growth under non-sterile and sterile soils conditions (Table 5). Zinc applications and E. cloacae inoculation had no significant effect on total chlorophyll content at 30 days under unsterile and sterile soils but, there were large differences between the treatments at 60 days. The treatments E. cloacae + $\mathrm{ZnO}$ and $E$. cloacae $+\mathrm{ZnCO}_{3}$ were the superior treatments in this context which recorded values at 41.97 and 41.77 under unsterile soils and 45.93 and 43.87 under sterile soils, respectively, compared to the control at 60 days. 
The differences mostly were significant for $E$. cloacae $+\mathrm{ZnO}$ followed by $E$. cloacae $+\mathrm{ZnCO}_{3}$ treatments gave the highest dry weight under circumstances of non-sterile or sterile soils. It recorded 3.93 and 3.84 compared to control $2.67 \mathrm{~g}$ plant $^{-1}$ for unsterile soils and 4.91 and 4.15 compared to control $2.70 \mathrm{~g} \mathrm{plant}^{-1}$ for sterile soils at 30 days. Similarly trend as dry weight g plant $^{-1}$ are showed at 60 days. The increase in total chlorophyll content due to combined mineral fertilizer and inoculation of one or more organisms has been documented by several workers (Balamurgan \& Gunasekharan, 1996 and Devananda, 2000). Similarly, Biswas et al. (2000) and Senthilkumar (2003) have documented the increase in total chlorophyll content when using mineral fertilizer and inoculation with $E$. cloacae in wheat, corn and radish.

TABLE 5. Effect of $\mathrm{Zn}$ applications and $E$. cloacae inoculation on chlorophyll content and dry weight $\left(\mathrm{g} \mathrm{plant}^{-1}\right)$ in Zea mays plant under sterile and Non-sterile soils at 30 and 60 days.

\begin{tabular}{|c|c|c|c|c|c|}
\hline \multicolumn{2}{|c|}{ Treatments } & \multicolumn{2}{|c|}{ Chlorophyll } & \multicolumn{2}{|c|}{ Dry weight } \\
\hline Main & Sub main & 30 days & 60 days & 30 days & 60 days \\
\hline \multirow{6}{*}{$\begin{array}{l}\text { Non-sterile } \\
\text { soil }\end{array}$} & Control & 29.90 & $40.40^{\mathrm{cd}}$ & $2.67^{\mathrm{g}}$ & $12.77^{\mathrm{h}}$ \\
\hline & E. cloacae & 31.10 & $41.50^{\mathrm{bc}}$ & $3.11^{\mathrm{f}}$ & $13.17^{\mathrm{g}}$ \\
\hline & $\mathrm{ZnO}$ & 31.17 & $40.90^{\mathrm{bc}}$ & $3.42^{\text {ef }}$ & $13.49^{\mathrm{fg}}$ \\
\hline & $\mathrm{ZnCO}_{3}$ & 30.33 & $40.40^{\mathrm{cd}}$ & $3.38^{\text {ef }}$ & $13.93^{\mathrm{e}}$ \\
\hline & E. cloacae $+\mathrm{ZnO}$ & 33.83 & $41.97^{b c}$ & $3.93^{\mathrm{bc}}$ & $14.98^{b c}$ \\
\hline & E. cloacae $+\mathrm{ZnCO}_{3}$ & 32.17 & $41.77^{b c}$ & $3.84^{\mathrm{bcd}}$ & $14.68^{\mathrm{cd}}$ \\
\hline \multirow{6}{*}{ Sterile soil } & Control & 28.53 & $38.03^{d}$ & $2.70^{\mathrm{g}}$ & $13.65^{\text {ef }}$ \\
\hline & E. cloacae & 30.97 & $41.37^{b c}$ & $3.34^{\text {ef }}$ & $14.51^{\mathrm{d}}$ \\
\hline & $\mathrm{ZnO}$ & 30.87 & $41.30^{\mathrm{bc}}$ & $3.60^{\text {cde }}$ & $14.62^{d}$ \\
\hline & $\mathrm{ZnCO}_{3}$ & 30.43 & $42.23^{\mathrm{bc}}$ & $3.48^{\mathrm{def}}$ & $14.52^{d}$ \\
\hline & E. cloacae $+\mathrm{ZnO}$ & 36.03 & $45.93^{\mathrm{a}}$ & $4.91^{\mathrm{a}}$ & $15.83^{\mathrm{a}}$ \\
\hline & E. cloacae $+\mathrm{ZnCO}_{3}$ & 32.43 & $43.87^{b}$ & $4.15^{b}$ & $15.22^{b}$ \\
\hline \multicolumn{2}{|c|}{ F. test } & n.s & $* *$ & $* *$ & $* *$ \\
\hline \multicolumn{2}{|c|}{ L.S.D 5\% } & -- & 2.04 & 0.31 & 0.32 \\
\hline \multicolumn{6}{|c|}{ Significance due to: } \\
\hline \multicolumn{2}{|c|}{ Main (soil) } & n.s & n.s & n.s & $* *$ \\
\hline \multicolumn{2}{|c|}{ L.S.D 5\% } & -- & -- & -- & 0.27 \\
\hline \multicolumn{2}{|c|}{ Sub main (treatment) } & $* *$ & $* *$ & $* *$ & $* *$ \\
\hline \multicolumn{2}{|c|}{ L.S.D $5 \%$} & 1.28 & 1.44 & 0.22 & 0.23 \\
\hline
\end{tabular}

The increase in dry weight of plant may be due to the effective specific $\mathrm{Zn}$ applications and E. cloacae inoculation used in the applied fertilizer and inoculum. Sarathambal et al. (2010) showed that the inoculation of Gluconacetobacter diazotrophicus in maize rhizosphere with ${ }^{65} \mathrm{ZnO}$ and ${ }^{65} \mathrm{ZnCO}_{3}$ increased the dry weight of plant compared to the control.

Ramesh et al. (2014) reported that inoculation significantly (with E. cloacae) enhanced shoot and seed dry weight up to 14 and $16 \%$, respectively, in soybean, and 39 and $49 \%$ in wheat compared to un-inoculated control.

Mehnaz et al. (2010) and Montañez et al. (2012) trend a similar increase in growth parameters with inoculation by Enterobacter.

Egypt. J. Microbiol. 51 (2016) 
Zinc content $\left(\mathrm{mg} \mathrm{kg}^{-1}\right)$

Data presented in Table 6 indicated that inoculation with E. cloacae alone or with different zinc applications variably increase zinc percentages of Zea mays. The highest content of $\mathrm{Zn}$ in plants were noted for inoculation with E. cloacae and $\mathrm{ZnO}$ (57.48 and $56.71 \mathrm{mg} \mathrm{kg}^{-1}$, respectively) followed by inoculation with $E$. cloacae and $\mathrm{ZnCO}_{3}$ (51.43 and $48.86 \mathrm{mg} \mathrm{kg}^{-1}$, respectively) under non-sterile and sterile soils at 30 days. A similar trend of $\mathrm{Zn}$ content occurred at 60 days.

TABLE 6. Effect of $\mathrm{Zn}$ applications and $E$. cloacae inoculation on Zinc content (mg $\mathrm{kg}^{-1}$ ) in Zea mays plant under sterile and Non-sterile soils at 30 and 60 days.

\begin{tabular}{|c|c|c|c|}
\hline \multicolumn{2}{|c|}{ Treatments } & \multicolumn{2}{|c|}{$\mathrm{Zn}\left(\mathrm{mg} \mathrm{kg}^{-1}\right)$} \\
\hline Main & Sub main & 30 days & 60 days \\
\hline \multirow{6}{*}{ Non-sterile soil } & Control & $37.57^{d}$ & $47.78^{f}$ \\
\hline & E. cloacae & $60.65^{a}$ & $68.32^{\mathrm{ab}}$ \\
\hline & $\mathrm{ZnO}$ & $50.55^{\text {bc }}$ & $62.51^{d}$ \\
\hline & $\mathrm{ZnCO}_{3}$ & $39.33^{d}$ & $52.31^{\mathrm{e}}$ \\
\hline & E. cloacae $+\mathrm{ZnO}$ & $57.48^{\mathrm{a}}$ & $70.35^{a}$ \\
\hline & E. cloacae $+\mathrm{ZnCO}_{3}$ & $51.43^{b c}$ & $65.46^{\mathrm{c}}$ \\
\hline \multirow{6}{*}{ Sterile soil } & Control & $34.15^{\mathrm{e}}$ & $44.77^{\mathrm{g}}$ \\
\hline & E. cloacae & $53.14^{b}$ & $67.85^{b}$ \\
\hline & $\mathrm{ZnO}$ & $47.90^{\mathrm{c}}$ & $60.76^{d}$ \\
\hline & $\mathrm{ZnCO}_{3}$ & $38.64^{\mathrm{d}}$ & $49.61^{\mathrm{f}}$ \\
\hline & E. cloacae $+\mathrm{ZnO}$ & $56.71^{\mathrm{a}}$ & $70.55^{a}$ \\
\hline & E. cloacae $+\mathrm{ZnCO}_{3}$ & $48.86^{\mathrm{c}}$ & $67.47^{b c}$ \\
\hline \multicolumn{2}{|c|}{ F. test } & $*$ & $* *$ \\
\hline \multicolumn{2}{|c|}{ L.S.D 5\% } & 3.41 & 2.18 \\
\hline \multicolumn{4}{|c|}{ Significance due to } \\
\hline \multicolumn{2}{|c|}{ Main (soil) } & *** & n.s \\
\hline \multicolumn{2}{|c|}{ L.S.D 5\% } & 2.65 & -- \\
\hline \multicolumn{2}{|c|}{ Sub main (treatment( } & $* *$ & * \\
\hline \multicolumn{2}{|c|}{ L.S.D 5\% } & 2.41 & 1.54 \\
\hline
\end{tabular}

The inoculation of $E$. cloacae with $\mathrm{ZnO}$ and $\mathrm{ZnCO}_{3}$ increased the available zinc content in the soil. However, the available zinc content was greater in nonsterile than the sterile soils conditions. This clearly indicated that microorganism other than E. cloacae may also involve the solubilization of insoluble zinc sources. Zinc solubilizing potential of a few bacterial genera namely Pseudomonas fluorescens, Thiobacillus ferroxidans, Bacillus spp. and $T$. thiooxidans have been reported (Hutchins et al., 1986 and Di Simine et al., 1998).

Sarathambal et al., (2010) Irrespective of soil types, the inoculation of Gluconacetobacter diazotrophicus showed higher plant zinc content. The total zinc content was more in unsterile zinc deficient soil. This may due to more zinc available due to solubilization of insoluble zinc compounds by soil microorganisms or G. diazotrophicus in non-sterile soil. On the other hand, Pascal (1962) reported the application of $\mathrm{ZnO}$ with $G$. diazotrophicus showed better uptake of the nutrient. $\mathrm{ZnO}$ is a sparingly soluble compound $\left(3-5 \times 10^{4} \mathrm{~g}^{-1} 100^{-1}\right.$ water at $25^{\circ} \mathrm{C}$ ) compared to $\mathrm{ZnCO}_{3}$ which might be the added advantage of $\mathrm{ZnO}$. 


\section{Conclusions}

The artificial application of zinc as fertilizer in crop production increases cost of cultivation. The available $\mathrm{Zn}$ in soil in different forms may be unavailable to plants, but it can be solubilized by inoculating with $\mathrm{Zn}$ solubilizing bacterial species.

Zinc solubilization depends on the metabolic activities of microorganisms. Many factors such as nitrogen and carbon sources may affect the efficiency of solubilization. In this research, E. cloacae was able to solubilize $\mathrm{Zn}$ compounds with a wide range of nutrients.

The over-all results of the present study suggest that ZSB inoculation with zinc oxide would be a better results for the present $\mathrm{Zn}$-fertilization, which could also improve crop growth and improve soil fertility.

\section{References}

Abdel-Hafez, A.M. (1966) Some studies on acid producing microorganisms in soil and rhizosphere with special reference to phosphate dissolvers. Ph.D. Thesis, Ain Shams University, Cairo, Egypt.

Allen, O.N. (1959) “Experiments in Soil Bacteriology”. Burgess pub. Co., Ninn, Minnesota.

Balamurgan, S. and Gunasekharan, S. (1996) Effect of combined inoculation of Rhizobium sp. and phosphobacteria at different levels of phosphorus in groundnut. Madras Agric. J. 83, 503-505.

Bergey, D. H. and Holt, J. G. (1984) Classification of Bacteria Form” Bergey's Manual of Determination Bacteriology," $1^{\text {st }}$ ed. (4).

Biswas, J., Ladha, J., Dazzo, F., Yanni, Y. and Rolf, B. (2000) Rhizobial inoculation influences seedling vigour and yield of rice. Agron. J. 92, 880-886.

Cakmak, I. (2008) Enrichment of cereal grains with zinc: agronomic or genetic biofortification? Plant Soil, 302, 1-17.

Cottenie, A., Verloo, M., Kiekens, L., Velgh, G. and Camerlynck, R. (1982) Chemical Analysis of Plants and Soils. P. 44-45. State Univ. Ghent Belgium, 63.

Devananda, B.J. (2000) Role of plant growth promoting rhizobacteria on growth and yield of pigeonpea (Cajanus cajan L.) cultivars. M.Sc. (Agric.) Thesis, Univ. Agric. Sci., Dharwad, India.

Di Simine, C.D., Sayer, J.A. and Gadd, G.M. (1998) Solubilization of zinc phosphate by a strain of Pseudomonas fluorescens isolated from a forest soil. Biol. Fertil. Soils, 28 (1), 87-94.

Drosinos, E.H. and Board, R.G. (1994) Metabolic activities of pseudomonads in batch cultures in extract of minced lamb. J. Appl. Bacteriol. 77, 613-620.

Egypt. J. Microbiol. 51 (2016) 
Fageria, N. K. (2002) Influence of micronutrients on dry matter yield and interaction with other nutrients in annual crops. Pesq. Agropec. Bras. 37, 1765-1772.

FAO, (2011) FAO Statistical Year. http://faostat.fao.org.

Fasim, F., Ahmed, N., Parsons, R. and Gadd, G.M. (2002) Solubilization of zinc salts by a bacterium isolated from the air environment of a tannery. FEMS Microbiol. Lett. 213, 1-6.

Hafeez, B., Khanif, Y.M. and Saleem, M. (2013) Role of zinc in plant nutrition- A Review. American Journal of Experimental Agriculture. 3 (2), 374-391.

Harris, D., Rashid, A., Mira, G., Arif, M. and Shah, H. (2007) 'On-farm’ seed priming with zinc sulphate solution - a cost-effective way to increase the maize yields of resource-poor farmers. Field Crops Res. 102,119-127.

Hossain, M.A., Jahiruddin, M., Islam, M.R. and Mian, M.H. (2008) The requirement of zinc for improvement of crop yield and mineral nutrition in the maize-mungbean-rice system. Plant Soil, 306, 13-22.

Hutchins, S.R., Davidson, M.S., Brierey, J.A. and Brierley, C.L. (1986) Microorganisms in reclamation of metals. Ann. Rev. Microbiol., 40, 311-336.

Imtiaz, M. (1999) Zn deficiency in cereals. PhD Thesis, Reading University, U.K.

Iqbal, U., Nazia, J., Iftikhar, A. and Hasnain, S. (2010) Effect of zinc phosphate-solubilizing bacterial isolates on growth of Vigna radiate. Ann. Microbiol. 60, 243-248.

Lindsay, L. and Norvel, W.A. (1978) Development of DTPA soil test for zinc, iron, manganese and copper. Soil Sci. Soc. Am. J. 42, 421-428.

Mehnaz, S., Kowalik, T., Reynolds, B. and Lazarovits, G. (2010) Growth promoting effects of corn (Zea mays) bacterial isolates under green house and field conditions. Soil Biol. Biochem. 42, 1848-1856.

Montañez, A., Blanco, A.R., Barlocco, C., Beracochea, M. and Sicardi, M. (2012) Characterization of cultivable putative endophytic plant growth promoting bacteria associated with maize cultivars (Zea mays L.) and their inoculation effects in vitro. Appl. Soil Ecol. 58, 21-28.

Morley, G.F., Sayer, J.A., Wilkinson, S.C., Gharieb, M.M. and Gadd, G.M. (1996) Fungal sequestration, solubilization and transformation of toxic metals. In: "Fungi and Environmetal Change” Frankland, J.C., Magan, N. and Gadd, G.M.. (Ed.), pp. 235-256. Cambridge University Press, Cambridge.

Nautiyal, C.S., Bhadauria, S., Kumar, P., Lal, H., Mondal, R. and Verma, D. (2000) Stress induced phosphate solubilization in bacteria isolated from alkaline soils. FEMS Microbiol. Lett. 182, 291-296.

Nuss, E.T. and Tanumihardjo, S.A. (2010) Maize: A paramount staple crop in the context of global nutrition. Comp. Rev. Food Sci. Food Saf. 9, 417-436. 
Parker, D.R., Aguilera, J.J. and Thomason, D.N. (1992) Zinc-phosphorus interactions in two cultivars of tomato (Lycopersicon esculentum L.) grown in chelator-buffered nutrient solutions. Plant Soil, 143, 163-177.

Pascal, P. (1962) Nouveau Traie de chimie Minerale, Vol. V, Masson, Paris

Potarzycki, J. and Grzebisz, W. (2009) Effect of zinc foliar application on grain yield of maize and it's yielding components. Plant Soil Environ. 55, 519-527.

Ramesh, A., Sharma, S.K., Sharma, M.P., Yadav, N. and Joshi, O.P. (2014) Inoculation of zinc solubilizing Bacillus aryabhattai strains for improved growth, mobilization and biofortification of zinc in soybean and wheat cultivated in Vertisols of central India. Appl. Soil Ecol. 73, 87-96.

Saeed, M. and Fox, R. L. (1977) Relation between suspension $\mathrm{pH}$ and Zn solubility in acid and calcareous soils. Soil Science, 124, 199-204.

Sarathambal, C., Thangaraju, M., Paulraj, C. and Gomathy, M. (2010) Assessing the Zinc solubilization ability of Gluconacetobacter diazotrophicus in maize rhizosphere using labelled ${ }^{65} \mathrm{Zn}$ compounds. Indian J. Microbiol. 50,103-109.

Saravanan, V.S., Subramanian, R. and Raj, A. (2003) Assessing in vitro solubilization potential of different zinc solubilizing bacterial (zsb) isolates. Brazilian, J. Microbiology, 34, 121125 .

Senthilkumar, M. (2003) Evaluating diazotrophic diversity and endophytic colonization ability Azorhizobium caulinodans and Methylobacterium sp. in bacterised and biotized rice (Oryza sativa L.). Ph.D. Thesis, Tamil Nadu Agricultural University, Coimbatore, India.

Shivay, Y.S., Kumar, D., Prasad, R. and Ahlawat, I.P.S. (2008) Relative yield and zinc uptake by rice from zinc sulphate and zinc oxide coatings onto urea. Nutr. Cycl. Agroecosyst., 80, 181-188.

Sillanpaa, M. (1990) Micronutrients assessment at the country level. An international Study FAO Soils Bulletin 63. Food and Agriculture Organization of the United Nations.

Somasegaran and Hoben (1985) Methods in legume Rhizobium technology prepared under USA Agency for International Developments.

Steel, G.D. and Torrie, J.H. (1981) "Principles and Procedures of Statistics, a Biometric Approach", $2^{\text {nd }}$ ed. McGraw Hill, New York.

Vallee, B.L. (1991) Introduction to metallothionein. Methods Enzymol. 205, 3-7.

Whiting, S.N., de Souza, M.P. and Terry, N. (2001) Rhizosphere bacteria mobilize Zn for hyperaccumulation by Thalaspi caerulescens. Environ. Sci. Technol., 35, 3144-3150.

( Received 18 /7 /2016;

accepted $3 / 10 / 2016)$

Egypt. J. Microbiol. 51 (2016) 


\title{
عزل وتعريف البكتيريا المذيبة للزنك ومدى كفائتها على نمو نبات

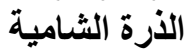

\author{
علاء الاين عبد الغفار عمارة ، عزة عبد السلام غازي و ابراهيم عبد العظيم الاخضر

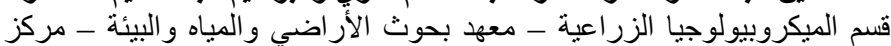

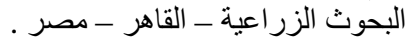

\begin{abstract}
تم عزل مر عزلة بكتيرية من الكمبوست الناضج وذللك بغرض تقييم إمكانية

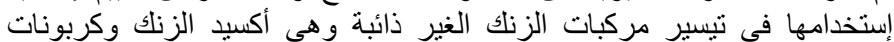

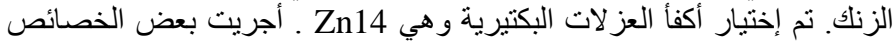

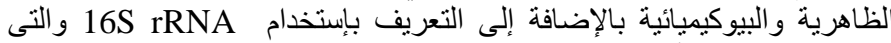
أسفرت نتائجها عن أن هذه العزلة هي بلى Enterobacter cloacae.

تم دراسة تأثير مصادر الكربون و النيتروجين على كفاءة الذوبان لمركبات

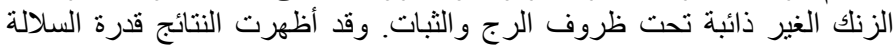
على إذابة مركبات الزنك تحت مدى واسع من المصادر الغذائية.

أجريت تجربة أصص بمحطة البحوث الزر اعية - سخا ـ كفر الشيخ - مصر وذللك كمذي

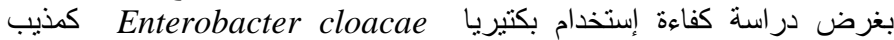

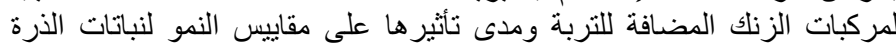

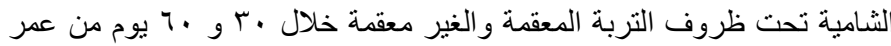
النبات.

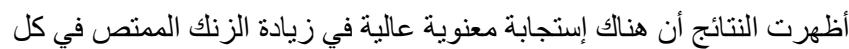

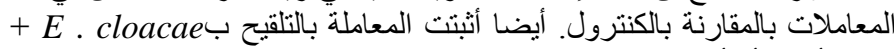
ZnO للنبات (جرام/ نبات) وذللك بالمقارنة بالكنترول.
\end{abstract}

لذا، نخلص من هذه الدراسة أن التلقيح بيكتيريا Enterobacter cloacae بياهم في تيسير مركبات الزنك الغير ذائبة للنبات مما يؤدى إلى لئى زيادة نمو النبات وكذا المحافظة على خصوبة التربة. 